○伊滕秀德依滕孝尾和久井上昭浩

1.まえがき （株式会社東芝）

電球形筫光ランプ「ネオボール」の効率问上のために, アマルカム封入の登光管を開発し たが，この䛂光管は主アマルガムの他に光束立り上り改善用補助アマルガムを付加して扣り， その基本的特性について報告する。

\section{2. ランプ棈造}

電極部の構造を中心に本ランブの構造を図1に示す。点 灯安定時の管内水銀蒸気压を制御する主アマルカ厶を排気 管内飞封入し, 始動初期の光束立ち上りを改善する補助了 マルカムはウェルズに設瞋した。ランプを消灯すると、管 内の水銀蒸父の一部は補助アマルカ厶八吸看される。ラン プを再点灯持る, フィラメントの熱で補助アマルガムの 水銀は急速に蒸發し管内几拡散される。

3.アマルガムの諸特性

主アマルガムの間囲温度特性を図2に示す。ランプ周四 治度 $25{ }^{\circ} \mathrm{C}$. 主アマルガム盜度 $900^{\circ} \mathrm{C}$ 前後で最適登光を得るよ $5 儿$ 組成を選定している。函 3 は基体金属の材質と光束立

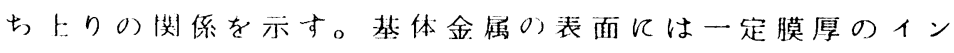
シウムをメッキして扣り，基体金虐として筧，板，網状の むのなどを試験した。点灯後約 30 秒で安定時の80\%以上 の光束となる。

\section{4. 消灯時の水銀移動現像}

消灯後の経過時間を変えたランプを破壊し, 管内の水銀 量分布を吸光光度法で测定した。主, 補アマルガム中と, アマルガム以外の管内水銀量の時間变化を図4 几示す。消 灯後経過時閏とと屯に主アマルガム门の水銀量は減少し,

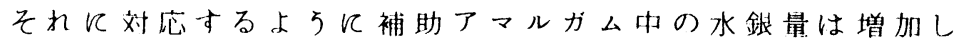
ている。補助アマルガムへ吸着される水銀量 $\mathrm{M}(\mu \mathrm{g})$ は, 消 灯後の絴過時116 T(分)に刘し，(1)式で近似できる。

$$
M=6.3 \sqrt{T}
$$

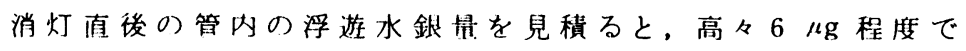
あり上式(1)飞代入し, 浮遊水銀がアルカムへ吸着される 時間を兒程ると約了分となる。

\section{参考文献}

(1)伊滕他; ネオボールの効䇣向上, 東芝レビニ一。

$$
\text { 39-11（昭59）995 }
$$

(2) A. Bouwknegt; Compact fluorescent lamps. J. III um.

$$
\text { Engng.Soc.1 1-4(1982) } 204
$$
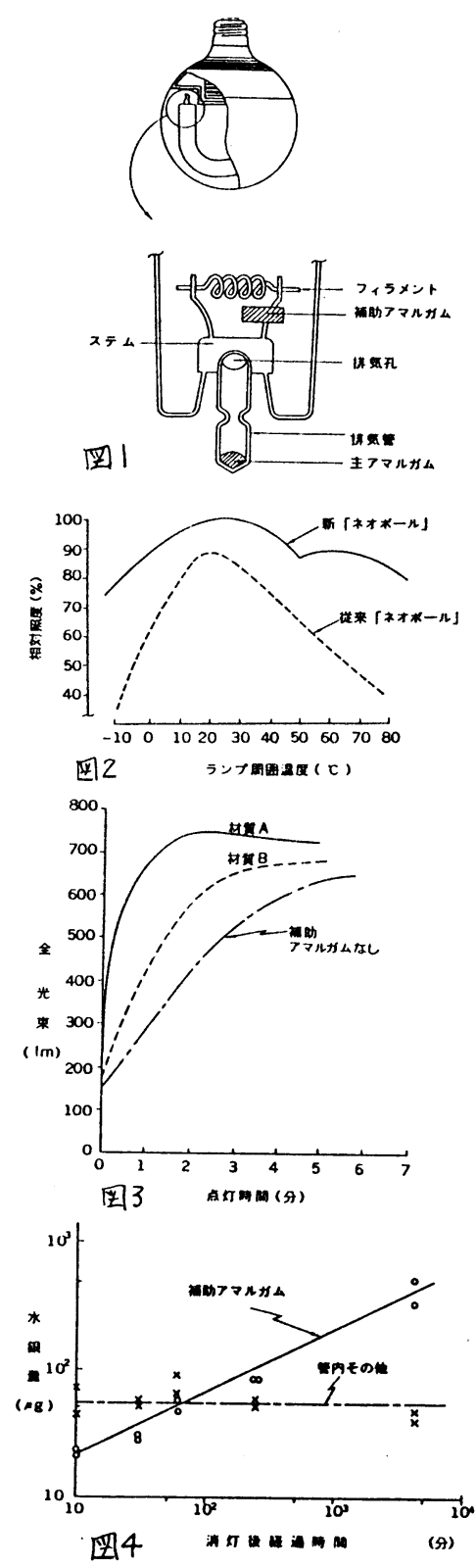

Behaviors of mercury in a compact fluorescent lamp dosed with the amalgam.

Hidenori Itō , Takashi Yorifuji , Kazuhisa Ogishi , Akihiro Inouye, 